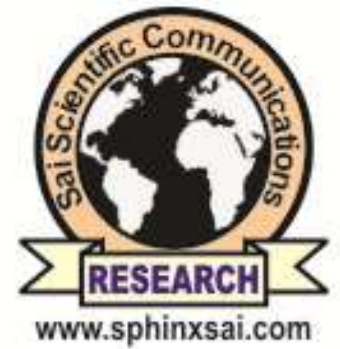

\title{
International Journal of PharmTech Research
} CODEN (USA): IJPRIF, ISSN: 0974-4304, ISSN(Online): 2455-9563

Vol.13, No.03, pp 142-152,

2020

\section{Effect of different biopesticides on mortality and their synergetic effect on the fecundity of Tribolium castaneum (Herbst, 1797)}

\author{
Muhammad Musa Khan ${ }^{1}$, Junaid Ali Siddiqui ${ }^{2}$, \\ Rana Muhammad Kaleem Ullah ${ }^{3}$, Muhammad Fahim Raza ${ }^{4}$
}

${ }^{1}$ Key Laboratory of Bio-Pesticide Innovation and Application, Engineering Research Centre of Biological Control, South China Agricultural University, 510642 Guangzhou, P. R. China.

${ }^{2}$ Red Imported Fire Ant Research Center, South China Agriculture University, Guangzhou, 510642, P. R. China.

${ }^{3}$ Hubei Insect Resources Utilization and Sustainable Pest Management Key Laboratory, College of Plant Science and Technology, Huazhong Agricultural University, Wuhan, P.R. China.

${ }^{4}$ State Key Laboratory of Agricultural Microbiology, Key Laboratory of Horticultural Plant Biology (MOE), China-Australia Joint Research Centre for Horticultural and Urban Pests, Institute of Urban and Horticultural Entomology, College of Plant Science and Technology, Huazhong Agricultural University, Wuhan, P. R. China.

\begin{abstract}
Tribolium castaneum is an important stored grain pest. T. castaneum not only caused heavy losses in stored grain products, but it also becomes resistant to many pesticides, which makes pests more important. Synergism is an important tool to reduce the risk of the development of resistance. This study was designed to investigate the toxicity, synergism effect, and effect of the combination of different biopesticides on the fecundity of T. castaneum Results showed that among six biopesticides (Spinosad, Abamectin, Azadiractin, Rosemary oil, Metarhizium anisopliae, and Verticillium lecanii) the spinosad, rosemary oil, and M. anisopliae exerted maximum percent mortality. When these pesticides were mixed and used to assess the synergistic effect. Results revealed that spinosad + Rosemary oil was the most effective combination, and exerting caused more mortality as compared to spinosad $+M$. anisopliae and rosemary oil $+M$. anisopliae. Results also showed that the number of eggs laid per day was also recorded less in the insects which were exposed to spinosad + rosemary oil as compared to other treatments. The percent reproductive control was about $43 \%$ in spinosad + Rosemary oil combination as compared to other treatments. This study showed that the use of different pesticides with a different mode of action in small concentration can be more effective than a single pesticide with high concentration. This technique will effectively deal with pesticide resistance and also economical for the store owners.
\end{abstract}

Keywords : Bio-pesticides, Botanical pesticides, Entomopathogenic fungi, Fecundity, Percent Reproduction Control, Tribolium castaneum.

Muhammad Musa Khan et al /International Journal of PharmTech Research, 2020,13(3): 142-152.

DOI= http://dx.doi.org/10.20902/IJPTR.2019.130303 


\section{Introduction}

Worldwide more than 2 billion tons of different grains, including cereals, oilseeds, and pulses, are produced per year to meet the nutritional requirements of humans and other domesticated animals. The storage of these grains is also very important for a long term food availability in case of famine and other natural calamities ${ }^{1}$. Post-harvest losses cannot be assessed accurately due to insufficient reports. In developed countries with well-managed storage conditions, the losses were estimated by up to $1-2 \%$, while in developed countries with poor management, the losses are 20 to $50 \%{ }^{2,3}$. Stored grains are susceptible to the attack of a variety of insect and mite pests. Stored-product insects pest have an economic influence on stored bulk grain and processed commodities ${ }^{4}$.

Tribolium castaneum was known as red flour beetle, which is believed to be of Indo-Australian origin ${ }^{5}$ but is currently a worldwide insect pest of great economic significance in stored product environments ${ }^{6,7}$. Previous studies showed that adults of T. Castaneum in uncontrolled and optimum conditions could cause $50 \%$ losses in stored grains?

Some medicinal and spice plant contains "secondary plant metabolites" which may act as kairomones, allomones, stimulants or deterrents of feeding and oviposition, and as antifeedants, insecticides and insect hormone mimic. Many plant allelochemicals, including azadirachtin, nicotine, pyrethrins, and rotenoids, have been developed as commercial insecticides ${ }^{8,9}$. Entomopathogenic fungi are considered promising microbial control agents for the control of post-harvest insects pest, and their evaluation for this purpose has lately attracted a significant amount of research. They are naturally occurring, environmentally safe organisms that infect insects by contact. Insect fungal pathogens have a broad spectrum of hosts, can be mass-produced easily, rapidly, and economically and can be applied with the same technical means as conventional contact insecticides ${ }^{10}$. The use of entomopathogenic fungi and botanicals is emphasized due to their environmentalfriendly nature to control stored product insects and mites in the laboratory and field-scale trials ${ }^{11}$.

The stored grain pests almost became resistant to synthetic chemicals due to the unfair use of insecticides, especially phosphine ${ }^{12,13}$. The incidence of pesticide resistance is a growing problem in storedproduct protection. More than 500 species of mites and insect pests are reported to resistant against one or more than one pesticides ${ }^{14}$. Stored product insect pests were found to be resistant against several insecticides including bioresmethrin, carbaryl, chlorpyrifos, chlorpyrifos-methyl, cyanophos, cyfluthrin, cyhalothrin, cypermethrin, DDT, deltamethrin, diazinon, dichlorvos, ethylene dibromide, fenitrothion, lindane, malathion, methyl bromide, permethrin, phosphine, phoxim, pirimiphos-methyl, promecarb, propoxur, pyrethrins, temephos, tetrachlorvinphos ${ }^{15}$. Previously many studies reported the synergistic effect of pesticides against several insects of stored products had shown synergism. The combination of different modes of action could also reduce the development of resistance ${ }^{16}$.

In this specific study, different bio-pesticides were used to assess the toxicity of these insecticides against $T$. castaneum. Three highly effective insecticides drawn on the basis of individual pesticide toxicity bioassay and were combined and subjected to assess the synergistic effect of these insecticides on mortality and the fecundity of $T$. castaneum.

\section{Materials and Methods}

\section{Insect rearing}

Wild type population of Tribolium castaneum was collected different stored products infected with red flour beetle from different storage facilities. Collected insects were reared under laboratory conditions in an incubator at $30 \pm 2{ }^{\circ} \mathrm{C}$ temperature and $60 \pm 5 \%$ relative humidity on wheat flour obtained from sterilized wheat grains. The insect was reared for more than three generations before use for experimentation.

\section{Insecticides}

Six different bio-pesticides formulations were used in this experiment. Commercially available formulations were purchased from different pesticide stores. These pesticides were diluted for different concentrations at the rate of $0.1 \mathrm{mg} / \mathrm{L}, 0.5 \mathrm{mg} / \mathrm{L}, 1.0 \mathrm{mg} / \mathrm{L}$ and $2.0 \mathrm{mg} / \mathrm{L}$ in water. The selection of 
concentrations was made on the basis of preliminary experiments. The information regarding pesticides, their recommended dose, and manufacturer information is provided in Table 1.

Table 1. Information regarding pesticide used in experimentation

\begin{tabular}{llll}
\hline Trade name & Active ingredient & Company & Formulation \\
\hline Tracer ${ }^{\circledR}$ & Spinosad & Dow Agro Sciences USA & $80 \mathrm{ml} /$ Acre \\
Abamectin ${ }^{\circledR}$ & Abamectin & Arysta Life Science & $18 \mathrm{~g} / \mathrm{L}$ \\
Margosom $^{\circledR}$ & Azadiractin & Agri-Life & $2 \mathrm{ml} / \mathrm{L}$ \\
EcoTrol $^{\mathrm{TM}}$ & Rosemary oil & KeyPlex & $100 \mathrm{~g} / \mathrm{L}$ \\
Pacer $^{\circledR}$ & Metarhizium anisopliae & Agri-Life & $5 \mathrm{~g} / \mathrm{L}$ \\
Mealikil ${ }^{\circledR}$ & Verticillium lecanii & Agri-Life & $5 \mathrm{~g} / \mathrm{L}$ \\
\hline
\end{tabular}

\section{Toxicity assessment bioassay of different pesticides against Tribolium castaneum}

For the assessment of the toxicity of different pesticides, the experiment was conducted in a $9 \mathrm{~cm}$ diameter petri dish. A filter paper of $9 \mathrm{~cm}$ diameter was socked in a single dilution for 2 minutes and air-dried for $15 \mathrm{~min}$ on room temperature. This filter paper was then laid down in the bottom of the petri dish. 20 (five days old) adults were released into the petri dishes. These insects were exposed to the pesticides for 6 hours on the basis of preliminary experiments and shifted into new jars containing wheat flour and covered with a black muslin cloth to prevent insects from escaping. After 3, 7, and 14 days, flour was sieved, and dead insects were counted. Each treatment was replicated four times.

\section{Synergistic effect of different pesticide}

After determination of toxicity of individual insecticides, three pesticides (i) one from chemical pesticides (Spinosad and Abamectin) (ii) one from botanical pesticides (Azadiractin and Rosemary oil) (iii) one from entomopathogenic fungal formulations (Metarhizium anisopliae and Verticillium lecanii) were selected on the basis of their high percent mortality. For the synergistic effect, the concentrations exerting $50 \%$ mortality in the first 7 days were selected. The pesticide concentrations were used in a 1:1 ratio in three different combinations (1) $A+B(2) B+C(3) A+C$. All the combinations were used to assess the mortality by the methods mentioned above.

\section{Fecundity of Tribolium castaneum}

To assess the effect of these pesticides on the fecundity of Tribolium castaneum, 500 $\mu 1$ of each concentration was mixed with $50 \mathrm{~g}$ of whole wheat flour. Control was established by mixing $500 \mu 1$ acetone with $50 \mathrm{~g}$ of wheat flour. T. Castaneum adults were sexed, as mentioned by ${ }^{17} .5$ females and 5 males (5 days old) were released in each jar. Each treatment was replicated 4 times. All the jars were kept in a controlled environmental chamber at $30 \pm 2{ }^{\circ} \mathrm{C}$ temperature and $55 \pm 5 \%$ R.H. After 3days, interval wheat flour was sieved with a 60-mesh sieve and the number of eggs collected in sieve were counted for next 33 days. The percent reproductive control (P.R.C.) was calculated as mentioned by Rizvi ${ }^{18}$.

$$
\text { P.R.C }=\frac{\text { Eggs laid by the female in control }- \text { Eggs laid by the female in treatement }}{\text { Eggs laid by the female in treatement }} \times 100
$$

\section{Statistical analysis}

The corrected mortality was calculated by the Abbott formula; the data transformation was done by $\left[\log _{10}(\sqrt{n})\right]$, where $\mathrm{n}$ is the value of corrected mortality. Data were analyzed by univariate analysis of variance, and the means were separated using Tukey test $(\mathrm{P}<0.05)$. Standard error bars computation and performance of statistical analysis were done by using the SPSS statistical software package version 20. Graphical work was performed with SigmaPlot 20.0. 


\section{Results}

\section{Toxicity of different pesticides against Tribolium castaneum}

Results Fig. 1 the mortality due to exposure of spinosad was significantly increased as the concentration increases $(\mathrm{F}=102.61 ; \mathrm{df}=3 ; \mathrm{P}<0.01)$ and days of application $(\mathrm{F}=68.83 ; \mathrm{df}=2 ; \mathrm{P}<0.01)$ (Fig. 1). The maximum $(98.68 \pm 1.32 \%)$ mortality was observed at $2 \mathrm{~g} / \mathrm{L}$ after 14 days of application. The $50 \%$ mortality was observed at $0.5 \mathrm{~g} / \mathrm{L}$ after 7 days of application $(55 \pm 3.08 \%)$ (Table 2$)$. Mortality due to exposure of abamectin was also significantly affected by the variation in concentrations $(\mathrm{F}=87.39 ; \mathrm{df}=3 ; \mathrm{P}<0.01)$ and days of application $(\mathrm{F}=74.17 ; \mathrm{df}=2 ; \mathrm{P}<0.01)$ (Fig.1). The 50\% mortality was achieved after 7 days of application at $1 \mathrm{~g} / \mathrm{L}$ $(59.54 \pm 4.42 \%)$, while maximum mortality was observed at $2 \mathrm{~g} / \mathrm{L}$ after 14 days of interval $(93.68 \pm 2.38 \%)$ (Table 2). The exposure of azadiractin at $1 \mathrm{~g} / \mathrm{L}$ gives $58.22 \pm 3.12 \%$ mortality after 7 days of exposure. Maximum mortality was observed after 14 days of the application when azadiractin was applied at the rate of 2 $\mathrm{g} / \mathrm{L}(81.84 \pm 3.34 \%)$ (Table 2). The variation in concentration and Post-application time have significant effect on mortality ( $\mathrm{F}=71.08,41.99 ; \mathrm{df}=3,2 ; \mathrm{P}<0.01$, respectively) (Fig. 1). Results in Table 2 also revealed that rosemary oil exerts $89.67 \pm 1.99 \%$ percent mortality in the response of application of $2 \mathrm{~g} / \mathrm{L}$ after 14 days, the shortest time to attain $50 \%$ mortality was 7 days at $1 \mathrm{~g} / \mathrm{L}$. Overall the variation in concentration and time after application have significant impact on $T$. castaneum mortality $(\mathrm{F}=84.23,66.74 ; \mathrm{df}=3,2 ; \mathrm{P}<0.01)$ (Fig. 1). The application of entomopathogenic fungal formulations of $M$. anisopliae attained $50.66 \pm 2.14 \%$ mortality in 7 days at $1 \mathrm{~g} / \mathrm{L}$ pesticide, and $V$. lecanii attained $61.45 \pm 2.05 \%$ mortality after 7 days of application of $2 \mathrm{~g} / \mathrm{L}$ pesticide (Table 2). The increase in concentrations and after application time have significant effect on mortality in M. anisopliae $(\mathrm{F}=59.55,98.82 ; \mathrm{df}=3,2 ; \mathrm{P}<0.01)$ and $V$. lecanii $(\mathrm{F}=57.77,34.27 ; \mathrm{df}=3,2 ; \mathrm{P}<0.01$ respectively) (Fig. 1). On the basis of the above results spinosad at the rate of $0.5 \mathrm{~g} / \mathrm{L}$, rosemary oil at the rate of $1 \mathrm{~g} / \mathrm{L}$ and $M$. anisopliae at the rate of $1 \mathrm{~g} / \mathrm{L}$ were selected. These pesticides were mixed in three different combinations (1) Spinosad+ M. anisopliae (2) Rosemary oil + Metarhizium anisopliae (3) Spinosad + Rosemary oil and subjected to assess their synergistic effect. 
Table 2. Percent mortality of different pesticides against Tribolium castaneum exposed to different concentrations.

\begin{tabular}{|c|c|c|c|c|c|c|c|}
\hline Chemical & Conc. & DAP & $\begin{array}{l}\text { Mortality } \\
(\%) \\
\text { Mean } \pm \text { SE }\end{array}$ & Chemical & Conc. & DAP & $\begin{array}{c}\text { Mortality (\%) } \\
\text { Mean } \pm \text { SE }\end{array}$ \\
\hline \multirow{12}{*}{ Spinosad } & \multirow{4}{*}{$0.1 \mathrm{~g} / \mathrm{L}$} & 3 days & $20.0 \pm 2.04$ & \multirow{12}{*}{ Abamectin } & \multirow{3}{*}{$0.1 \mathrm{~g} / \mathrm{L}$} & 3 days & $13.75 \pm 2.39$ \\
\hline & & 7 days & $26.91 \pm 2.40$ & & & 7 days & $25.20 \pm 3.35$ \\
\hline & & 14 days & $29.74 \pm 4.04$ & & & 14 days & $36.71 \pm 1.18$ \\
\hline & & 3 days & $35.0 \pm 3.54$ & & \multirow{4}{*}{$0.5 \mathrm{~g} / \mathrm{L}$} & 3 days & $26.25 \pm 3.75$ \\
\hline & \multirow{3}{*}{$0.5 \mathrm{~g} / \mathrm{L}$} & 7 days & $55.0 \pm 3.08$ & & & 7 days & $37.96 \pm 2.39$ \\
\hline & & 14 days & $66.18 \pm 1.78$ & & & 14 days & $51.78 \pm 3.82$ \\
\hline & & 3 days & $38.75 \pm 2.39$ & & & 3 days & $40.0 \pm 2.04$ \\
\hline & \multirow[t]{3}{*}{$1.0 \mathrm{~g} / \mathrm{L}$} & 7 days & $62.83 \pm 1.04$ & & \multirow[t]{3}{*}{$1.0 \mathrm{~g} / \mathrm{L}$} & 7 days & $59.54 \pm 4.42$ \\
\hline & & 14 days & $80.46 \pm 2.63$ & & & 14 days & $75.86 \pm 2.74$ \\
\hline & & 3 days & $41.25 \pm 2.39$ & & & 3 days & $46.25 \pm 2.39$ \\
\hline & \multirow[t]{2}{*}{$2.0 \mathrm{~g} / \mathrm{L}$} & 7 days & $76.91 \pm 3.26$ & & \multirow[t]{2}{*}{$2.0 \mathrm{~g} / \mathrm{L}$} & 7 days & $72.04 \pm 3.60$ \\
\hline & & 14 days & $98.68 \pm 1.32$ & & & 14 days & $93.68 \pm 2.38$ \\
\hline \multirow{12}{*}{ Azadiractin } & \multirow{3}{*}{$0.1 \mathrm{~g} / \mathrm{L}$} & 3 days & $11.25 \pm 2.39$ & & \multirow{3}{*}{$0.1 \mathrm{~g} / \mathrm{L}$} & 3 days & $11.25 \pm 2.39$ \\
\hline & & 7 days & $21.38 \pm 4.15$ & & & 7 days & $22.83 \pm 1.66$ \\
\hline & & 14 days & $25.92 \pm 3.55$ & & & 14 days & $31.18 \pm 2.18$ \\
\hline & \multirow{2}{*}{$0.5 \mathrm{~g} / \mathrm{L}$} & 3 days & $25.0 \pm 2.04$ & & \multirow{3}{*}{$0.5 \mathrm{~g} / \mathrm{L}$} & 3 days & $27.50 \pm 3.23$ \\
\hline & & 7 days & $39.14 \pm 2.78$ & & & 7 days & $37.96 \pm 2.39$ \\
\hline & \multirow{4}{*}{$1.0 \mathrm{~g} / \mathrm{L}$} & 14 days & $55.92 \pm 2.92$ & Rosemary & & 14 days & $57.24 \pm 2.71$ \\
\hline & & 3 days & $36.25 \pm 2.39$ & oil & \multirow[t]{2}{*}{$1.0 \mathrm{~g} / \mathrm{L}$} & 3 days & $35.0 \pm 2.04$ \\
\hline & & 7 days & $58.22 \pm 3.12$ & & & 7 days & $55.66 \pm 2.56$ \\
\hline & & 14 days & $71.51 \pm 3.05$ & & \multirow{4}{*}{$2.0 \mathrm{~g} / \mathrm{L}$} & 14 days & $74.08 \pm 1.84$ \\
\hline & \multirow[t]{3}{*}{$2.0 \mathrm{~g} / \mathrm{L}$} & 3 days & $45.0 \pm 4.56$ & & & 3 days & $47.50 \pm 3.23$ \\
\hline & & 7 days & $69.67 \pm 3.39$ & & & 7 days & $65.86 \pm 2.21$ \\
\hline & & 14 days & $81.84 \pm 3.34$ & & & 14 days & $89.67 \pm 1.99$ \\
\hline \multirow{12}{*}{$\begin{array}{l}\text { Metarhizium } \\
\text { anisopliae }\end{array}$} & \multirow[t]{3}{*}{$0.1 \mathrm{~g} / \mathrm{L}$} & 3 days & $12.70 \pm 1.57$ & & \multirow[t]{3}{*}{$0.1 \mathrm{~g} / \mathrm{L}$} & 3 days & $08.75 \pm 2.39$ \\
\hline & & 7 days & $25.26 \pm 2.74$ & & & 7 days & $16.51 \pm 3.60$ \\
\hline & & 14 days & $40.99 \pm 1.72$ & & & 14 days & $28.09 \pm 2.94$ \\
\hline & \multirow{2}{*}{$0.5 \mathrm{~g} / \mathrm{L}$} & 3 days & $21.58 \pm 2.58$ & & \multirow[t]{2}{*}{$0.5 \mathrm{~g} / \mathrm{L}$} & 3 days & $17.50 \pm 3.23$ \\
\hline & & 7 days & $29.14 \pm 3.22$ & & & 7 days & $25.59 \pm 3.43$ \\
\hline & \multirow{4}{*}{$1.0 \mathrm{~g} / \mathrm{L}$} & 14 days & $43.49 \pm 2.75$ & Verticillium & \multirow{3}{*}{$1.0 \mathrm{~g} / \mathrm{L}$} & 14 days & $39.67 \pm 2.89$ \\
\hline & & 3 days & $27.89 \pm 3.35$ & lecanii & & 3 days & $35.0 \pm 3.54$ \\
\hline & & 7 days & $50.66 \pm 2.14$ & & & 7 days & $43.55 \pm 2.31$ \\
\hline & & 14 days & $64.14 \pm 1.76$ & & & 14 days & $58.95 \pm 2.23$ \\
\hline & \multirow[t]{3}{*}{$2.0 \mathrm{~g} / \mathrm{L}$} & 3 days & $36.64 \pm 2.06$ & & $2.0 \mathrm{~g} / \mathrm{L}$ & 3 days & $43.75 \pm 3.15$ \\
\hline & & 7 days & $62.04 \pm 3.14$ & & & 7 days & $61.45 \pm 2.05$ \\
\hline & & 14 days & $88.55 \pm 4.69$ & & & 14 days & $80.66 \pm 2.73$ \\
\hline
\end{tabular}

Conc. $=$ Concentrations; $\mathrm{DAP}=$ Days after exposure 

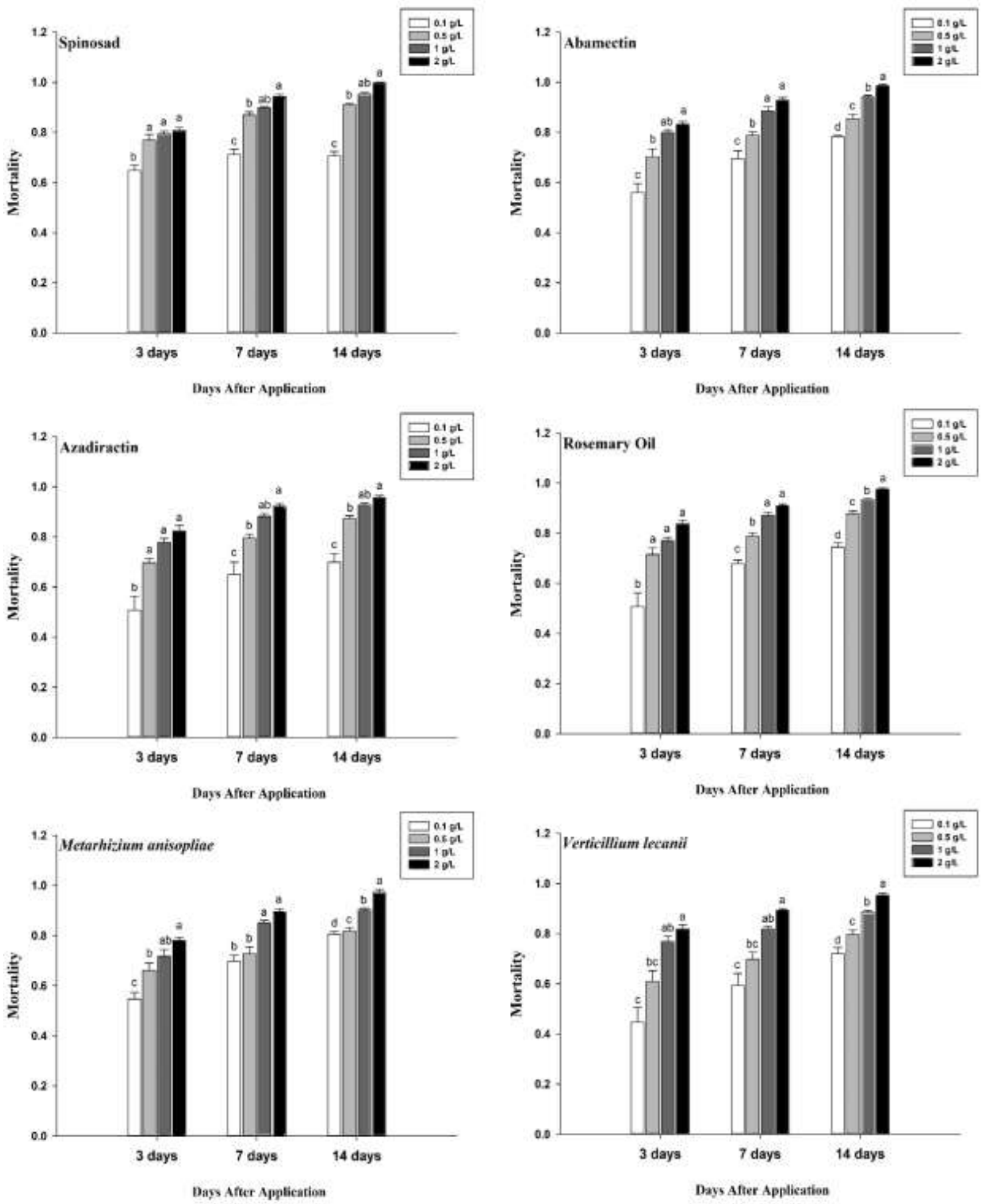

Fig. 1. Mortality of different pesticides after 3, 7, and 14 days. Each bar is the mean value of four replications treated with $0.1,0.5,1.0$, and $2.0 \mathrm{mg} / \mathrm{L}$. Error bars are showing a standard deviation of mean at a $95 \%$ confidence interval. The same lettering is showing the non-significant difference between means. 


\section{Synergistic effects of three pesticides against Tribolium castaneum}

When the different combinations of pesticides subjected for assessment of mortality due to synergistic effect, results in Fig. 2 showed that all the combinations $(\mathrm{f}=12.81 ; \mathrm{df}=2 ; \mathrm{p}<0.01)$ and days $(\mathrm{f}=145.20 ; \mathrm{df}=2$; $\mathrm{p}<0.01$ ) exerted a significant effect on the mortality of $T$. castaneum. Results (Table 3 ) also revealed that the combination of spinosad + rosemary oil gives $100 \%$ mortality of adults after 14 days of application, while this percentage was $84.54 \pm 2.26$ and 83.22 \pm 3.43 in Spinosad+ M. anisopliae and Rosemary oil + M. anisopliae, respectively.

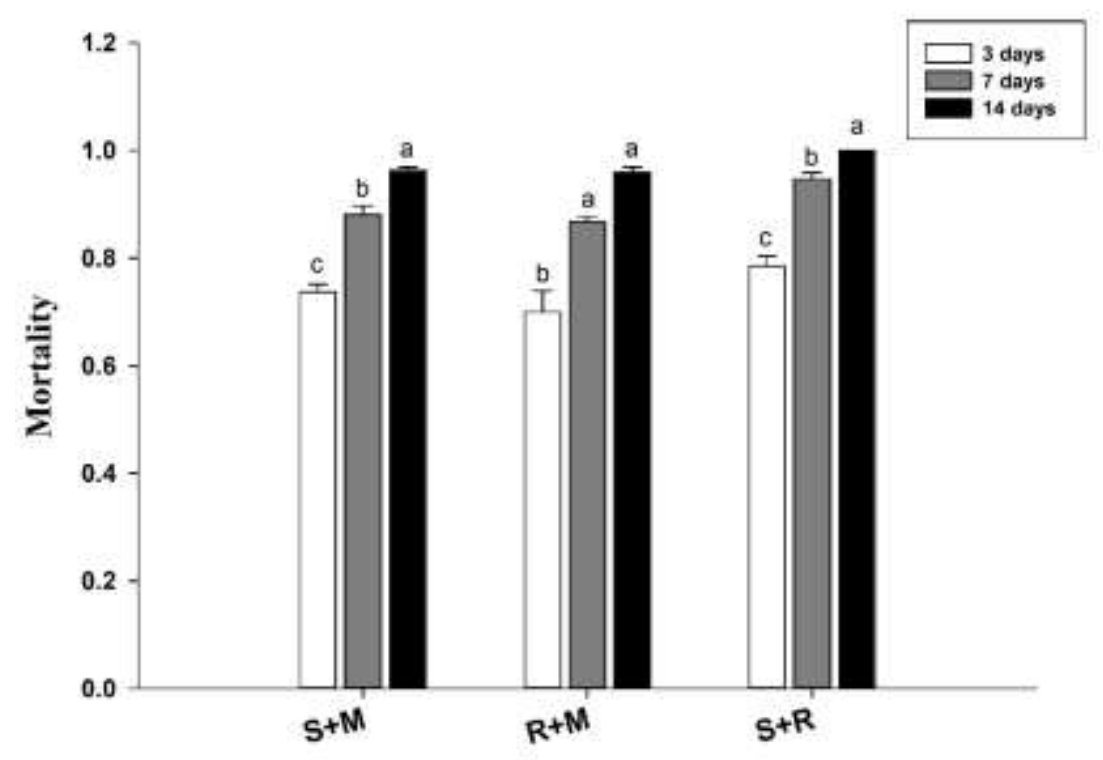

Fig. 2. Mortality of three pesticide combinations $(\mathbf{S}+\mathbf{M}=$ Spinosad + Metarhizium anisopliae; $\mathbf{R}+\mathbf{M}=$ Rosemary oil+Metarhizium anisopliae; $S+R=$ Spinosad+Rosemary oil) after 3, 7 and 14 days. Each bar is the mean value of four replications. Error bars are showing a standard deviation of mean at a 95\% confidence interval. The same lettering is showing the non-significant difference between means.

Table 3: Percent mortality of different pesticide combinations

\begin{tabular}{ccc}
\hline Combinations & DAP & $\begin{array}{c}\text { Mortality } \\
(\mathbf{\%}) \\
\text { Mean } \pm \text { SE }\end{array}$ \\
\hline Spinosad+Metarhizium anisopliae & 3 days & $30.0 \pm 2.04$ \\
(S+M) & $\mathbf{7}$ days & $58.22 \pm 4.25$ \\
& $\mathbf{1 4}$ days & $84.54 \pm 2.26$ \\
Rosemary oil+Metarhizium & $\mathbf{3}$ days & $26.25 \pm 4.27$ \\
anisopliae & $\mathbf{7}$ days & $54.34 \pm 2.61$ \\
(R+M) & $\mathbf{1 4}$ days & $83.22 \pm 3.43$ \\
& $\mathbf{3}$ days & $37.50 \pm 3.23$ \\
Spinosad+Rosemary oil & $\mathbf{7}$ days & $78.49 \pm 4.25$ \\
(S+R) & $\mathbf{1 4}$ days & $100 \pm 0.00$
\end{tabular}




\section{Fecundity of Tribolium castaneum}

When whole wheat flour was treated with different combinations of pesticides. Results that the number of eggs/day was significantly reduced in spinosad + rosemary oil treatment (4.18 \pm 0.18 eggs/day) as compared to that observed in spinosad $+M$. anisopliae $(5.58 \pm 0.23$ eggs/day) and rosemary oil + M. anisopliae $(6.11 \pm 0.13$ eggs/day). The maximum number of eggs observed in control (7.27 eggs/day) (Fig. 3). There was $42.27 \pm 3.02 \%$ reproduction control observed in spinosad + rosemary oil treatment as compared to that in spinosad+ $M$. anisopliae (23.23 $\pm 2.89 \%)$ and rosemary oil + M. anisopliae (15.73 $\pm 2.81 \%)$ (Fig. 4).

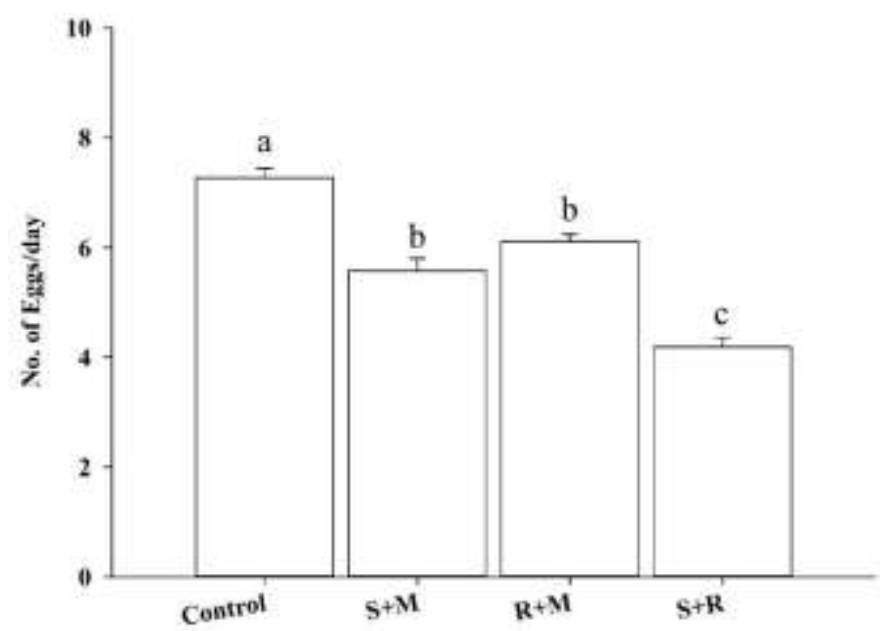

Fig. 3. Number of eggs laid by Tribolium castaneum per day. Treated with different pesticide combinations $(\mathrm{S}+\mathrm{M}=$ Spinosad+Metarhizium anisopliae; $\mathrm{R}+\mathrm{M}=$ Rosemary oil+Metarhizium anisopliae; $\mathrm{S}+\mathrm{R}=$ Spinosad+Rosemary oil) and control. Each bar is the mean value of four replications. Error bars are showing a standard deviation of mean at a $95 \%$ confidence interval. The same lettering is showing the non-significant difference between means.

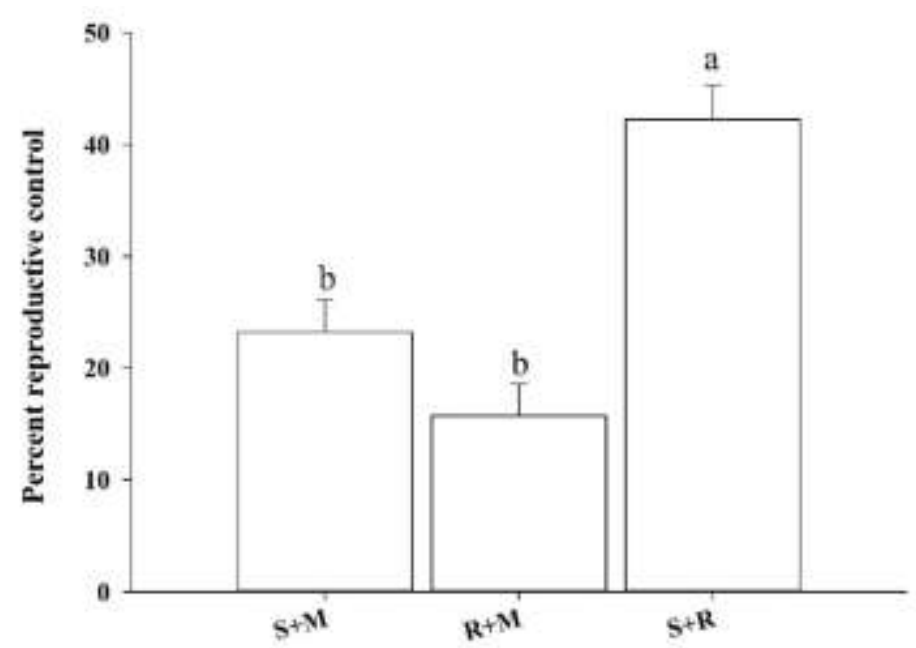

Fig. 4. Percent reproductive control of Tribolium castaneum. Treated with different pesticide combinations $(\mathrm{S}+\mathrm{M}=$ Spinosad+Metarhizium anisopliae; $\mathrm{R}+\mathrm{M}=$ Rosemary oil+Metarhizium anisopliae; $\mathbf{S}+\mathbf{R}=$ Spinosad+Rosemary oil). Each bar is the mean value of four replications. Error bars are showing a standard deviation of mean at a $95 \%$ confidence interval. The same lettering is showing the nonsignificant difference between means. 


\section{Discussion}

Insects on their own have a great potential to detoxify repeatedly applied toxic compounds by increasing the enzymatic metabolism of those compounds ${ }^{19,20}$. Synergists help to fight against such hypermetabolism of insecticides, hence increase their real efficacy at lower doses against resistant insects ${ }^{21,22}$.

Several studies reported the synergistic effect of different pesticides against stored grain pests. Ziaee ${ }^{23}$ reported the synergistic effect of Carum copticum essential oil on diatomaceous earth tested against Sitophilus granarius and $T$. confusum. The synergistic effect of spinosad with three botanical powders of Aframomum melegueta, Eugenia aromatica, and Piper guineense against $T$. castaneum was reported by Babarinde ${ }^{24}$. The synergistic effect of piperonyl butoxide and emamectin benzoate was assessed to determine the resistance level in T. castaneum Herbst by Awan ${ }^{25}$.

Metarhizium anisopliae was tested against black bug (Scotinophara courctata), and observations revealed that the black bug population was significantly reduced in the treated rice field due to the application of entomophagous fungi ${ }^{26}$. Batta $^{27}$ used M. anisopliae against Rhyzopertha dominica in Cicer arietinum. Results showed that exposure to the early stages of pests could cause a serious reduction in F1 progeny. Conidia suspended in distilled water or formulated in invert emulsion or wheat flour caused 56.7, 93.3, and 86.7\% mortality, respectively, 7 days after treatment.

Results of the application of azadiractin against $R$. dominica showed that the application of azadiractin on wheat grains at the rate of $5 \mathrm{mg} / \mathrm{Kg}$ reduced the $\mathrm{F} 1$ progeny emergence by $98 \%{ }^{28}$. Hussain ${ }^{29}$ examined six insecticides with novel modes of application such as abamectin (Sure 1.8 EC), spinosad (Tracer 240 SC), indoxacarb (Steward $150 \mathrm{SC}$ ), azadirachtin (Nimbokil $60 \mathrm{EC}$ ), buprofezin, and polychlorinated petroleum hydrocarbon (Tenekil 100 EC) against T.castaneum. Results show that abamectin was the most toxic of all insecticides applied in current study, followed by indoxacarb, spinosad, buprofezin, Tenekil $100 \mathrm{EC}$, and azadirachtin. These results somehow contradict the results of the present study, which showed that spinosad was the most effective pesticide against $T$. castaneum. Spinosad at the rate of $0.25 \%, 0.50 \%, 0.75 \%$ and $1.0 \%$ was used against $T$. castaneum. The results showed that as the concentration of pesticide increases the mortality of red flour beetle also increases. The mortality of insects in treatment was significantly different as compared to that in control ${ }^{30}$. Andric ${ }^{31}$ compared the effect of abamectin and spinosad on T. castaneum. The conclusion was drawn that if the spinosad and abamectin applied at the same rate of $5 \mathrm{mg} / \mathrm{Kg}$, the mortality recorded in spinosad exposed insects was $75 \%$ while in abamectin was $58 \%$, which showed that spinosad is more toxic for T. castaneum as compared abamectin.

Sabbour $^{32}$ reported that that $T$. castaneum was susceptible to $N$. riley, but larvae of $T$. castaneum were more tolerant of $V$. lecanii. Das ${ }^{33}$ used neem-based insecticide Nimbicidine ${ }^{\circledR}$ against $T$. castaneum, and results showed that insecticide significantly inhibited the hatching, pupation, and adult emergence of the beetle. Khanam $^{34}$ reported that the exposure of plant extracts to $T$. castaneum could cause a significant reduction in fecundity, fertility, and oviposition.

Ashraf ${ }^{35}$ reported that $M$. anisopliae, the combination of diatomaceous earth and thiamethoxam, was used to assess their mortality, progeny production, mycosis, and sporulation of different stored grain insect pests and reported that the combination of pesticides reduced a mean number of emerged adults.

\section{Conclusion}

On the basis of above-mentioned results the conclusion can be drawn that spinosad, rosemary oil and $M$. anisopliae are effective biopesticides against $T$. castaneum, but because of risk of the resistance development if these pesticides used in lower doses and mixed. The synergistic effect gives not only effective control of the adult population but also control the oviposition of $T$. castaneum. For the validation of the results of curent study, there is a need to conduct the experiment in storage places, which can providee a resistance-free control method and also helps to lower the post-harvest storage cost. 


\section{Acknowledgements}

We would like to appreciate the continuous support of Ms. Lina Cui from Daqing Foreign Language School, Daqing, Heilongjiang, China, for reviewing the manuscript. This research did not receive any specific grant as funding from any public, commercial, or not-for-profit funding agency. The authors declare no conflict of interest in this manuscript.

\section{References}

1. Jayas, D. S., Storing Grains for Food Security and Sustainability, Agric. Res., 2012, 1, 21-24.

2. Hill, D. S., Pests of stored products and their control 1st ed. Belhaven Press, London, 1990.

3. Hill, D. S., Pests of stored foodstuffs and their control Kluwer Academic Publishers, Norwell, 2002.

4. Khashaveh, A. and Chelav, H. S., Laboratory bioassay of iranian isolates of entomopathogenic fungus Metarhizium anisopliae (Metsch.) Sorokin (Ascomycota: Hypocreales ) against two species of storage pest, Agric. Conspec. Sci. cus, 2013, 78, 35-40.

5. Ridley, A. W., Hereward, J. P., Daglish, G. J., Raghu, S., Collins, P. J., and Walter, G. H., The spatiotemporal dynamics of Tribolium castaneum (Herbst): Adult flight and gene flow, Mol. Ecol., 2011, 20, 1635-1646.

6. Nenaah, G. E., Chemical composition, toxicity and growth inhibitory activities of essential oils of three Achillea species and their nano-emulsions against Tribolium castaneum (Herbst), Ind. Crops Prod., 2014, 53, 252-260.

7. Abdullahi, G., Muhamad, R., Dzolkhifli, O., and Sinniah, U. R., Damage potential of Tribolium castaneum (Herbst) (Coleoptera: Tenebrionidae) on cocoa beans: Effect of initial adult population density and post infestation storage time, J. Stored Prod. Res., 2018, 75, 1-9.

8. Khan, M. M., Huang, Q., Wagan, T. A., Hongxia, H., Wanlun, C., and Zhao, J., Behavioral response of Nilaparvata lugens (Stål), Cyrtorhinus lividipennis Reuter and Paederus fuscipes Curtis to three synthetic volatile chemical compounds, J. Asia. Pac. Entomol., 2020, 23, 2020.

9. Said, P. P. and Pashte, V. V., Botanicals: The Protectants of Stored Grains Pests, Trends Biosci., 2015, 8, 3750-3755.

10. Rumbos, C. I. and Athanassiou, C. G., Use of entomopathogenic fungi for the control of stored-product insects: can fungi protect durable commodities?, J. Pest Sci. (2004)., 2017, 90, 839-854.

11. Storm, C., Scoates, F., Nunn, A., Potin, O., and Dillon, A., Improving efficacy of Beauveria bassiana against stored grain beetles with a synergistic co-formulant, Insects, 2016, 7, 1-14.

12. Bell, C. H. and Wilson, S. M., Phosphine tolerance and resistance in Trogoderma granarium Everts (Coleoptera: Dermestidae), J. Stored Prod. Res., 1995, 31, 199-205.

13. Benhalima, H., Chaudhry, M. Q., Mills, K. A., and Price, N. R., Phosphine resistance in stored-product insects collected from various grain storage facilities in Morocco, J. Stored Prod. Res., 2004, 40, $241-$ 249.

14. Hemingway, J., Field, L., and Vontas, J., An overview of insecticide resistance, Science (80-. )., 2002, 298, 96-97.

15. Talukder, F., Pesticide Resistance in Stored-Product Insects and Alternative Biorational Management: A Brief Review, J. Agric. Mar. Sci., 2017, 14, 9.

16. Korunic, Z. and Rozman, V., A synergistic mixture of diatomaceous earth and deltamethrin to control stored grain insects, In Proceedings of the 10th International Working Conference on Stored-Product Protection 2010, pp. 894-898.

17. Halstead, D. G. H., External sex differences in stored-products Coleoptera, Bull. Entomol. Res., 1963, 54, 119-134.

18. Rizvi, S. J. H., Rizvi, V., and Mukerjee, D., 1,3,7-Trimethylxanthine, an allelochemical from seeds of Coffea arabica: Some aspects of its mode of action as a natural herbicide, Plant Soil, 1987, 98, 81-91.

19. Sun, Y. P. and Johnson, E. R., Synergistic and Antagonistic Actions of Insecticide-Synergist Combinations and Their Mode of Action, J. Agric. Food Chem., 1960, 8, 261-266.

20. Schama, R., Pedrini, N., Juárez, M. P., et al., Rhodnius prolixus supergene families of enzymes potentially associated with insecticide resistance, Insect Biochem. Mol. Biol., 2016, 69, 94-104.

21. Baki, M. A., Akhtar, N., Rahman, M. M., et al., action of Wedelia calendulacea Less. plant extracts with Lamda cyhalothrin on Adult Red Flour Beetle Tribolium castaneum Herbst, J. Agron., 2005, 4, 
$18-22$.

22. Giddings, J., Gagne, J., and Sharp, J., Synergistic effect of piperonyl butoxide on acute toxicity of pyrethrins to Hyalella azteca, Environ. Toxicol. Chem., 2016, 35, 2111-2116.

23. Ziaee, M., Moharramipour, S., and Francikowski, J., The synergistic effects of Carum copticum essential oil on diatomaceous earth against Sitophilus granarius and Tribolium confusum, J. Asia. Pac. Entomol., 2014, 17, 817-822.

24. Babarinde, S. A., Synergistic effect of spinosad with selected botanical powders as biorational insecticides against adults of Tribolium castaneum Herbst , 1797 ( Coleoptera : Tenebrionidae ), 2018, 1797.

25. Awan, D. A., Ahmad, F., Saleem, M. A., and Shakoori, A. R., Synergistic effect of piperonyl butoxide and emamectin benzoate on enzymatic activities in resistant populations of red flour beetle, Tribolium castaneum Herbst (Coleoptera: Tenebrionidae), Environ. Sci. Pollut. Res., 2019, 14200-14213.

26. Rombach, M. C., Aguda, R. M., Shepard, B. M., and Roberts, D. W., Entomopathogenic fungi (Deuteromycotina) in the control of the black bug of rice, Scotinophara coarctata (Hemiptera; Pentatomidae), J. Invertebr. Pathol., 1986, 48, 174-179.

27. Batta, Y. A., Control of the lesser grain borer (Rhyzopertha dominica (F.), Coleoptera: Bostrichidae) by treatments with residual formulations of Metarhizium anisopliae (Metschnikoff) Sorokin (Deuteromycotina: Hyphomycetes), J. Stored Prod. Res., 2005, 41, 221-229.

28. Rahim, M., Biological activity of azadirachtin-enriched neem kernel extracts against Rhyzopertha dominica (F.) (Coleoptera: Bostrichidae) in stored wheat, J. Stored Prod. Res., 1998, 34, 123-128.

29. Hussain, R., Riaz, M., Saleem, M. A., and Mastoi, M. I., Biochemical abnormalities induced by abamectin in sixth instar larvae of the red flour beetle, Tribolium castaneum (Herbst), Pakistan J. Agric. Res., 2015, 28.

30. Nadeem, M., Iqbal, J., Khattak, M. K., and Shahzad, M. A., Management of Tribolium castaneum (Hbst.) (Coleoptera: Tenebrionidae) using Neem (Azadirachta indica A. Juss) and Tumha (Citrullus colocynthis (L.)), Pak. J. Zool., 2012, 44, 1325-1331.

31. Andric, G., Kljajic, P., Peric, I., and Prazic Golic, M., Susceptibility of red flour beetle Tribolium castaneum ( Herbst ) populations from Serbia to contact insecticides, In 10th International Working Conference on Stored Product Protection Susceptibility 2010, pp. 869-873.

32. Sabbour, M., Efficacy of some microbial control agents and inorganic insecticides against red flour beetle Tribolium castaneum and confused flour beetle, Tribolium confusum ( Coleoptera: Tenebrionidae), Integr. Prot. Stored Prod., 2014, 98, 193-201.

33. Das, D. R., Parween, S., and Faruki, S. I., Efficacy of commercial neem-based insecticide, Nimbicidine ${ }^{\circledR}$ against eggs of the red flour beetle Tribolium castaneum (Herbst), Univ. J. Zool. Rajshahi Univ., 2007, 25, 51-55.

34. Khanam, L. A. M., Khan, A. R., Mahfuz, I., and Talukder, D., Antiovipositional and antifertility effects of plant extracts against the flour beetles, Tribolium castaneum (Herbst) and T. confusum (J. du Val), IOSR J. Agric. Vet. Sci., 2014, 7, 43-48.

35. Ashraf, M., Farooq, M., Shakeel, M., et al., Influence of entomopathogenic fungus, Metarhizium anisopliae, alone and in combination with diatomaceous earth and thiamethoxam on mortality, progeny production, mycosis, and sporulation of the stored grain insect pests, Environ. Sci. Pollut. Res., 2017, 24, 28165-28174. 